\title{
Determination of Density, Shear and Compression Parallel to the Grain Strengths of Pariri (Pouteria sp.), Brazilian Native Wood Specie
}

\author{
Diego Henrique de Almeida ${ }^{1, *}$, Eduardo Chahud ${ }^{2}$, Tiago Hendrigo de Almeida ${ }^{3}$, André Luís Christoforo ${ }^{4}$, \\ Luiz Antônio Melgaço Nunes Branco ${ }^{2}$, Francisco Antonio Rocco Lahr ${ }^{5}$ \\ ${ }^{1}$ Pitágoras Faculty, Department of Engineering, Poços de Caldas Campus, Poços de Caldas, Brazil \\ ${ }^{2}$ Faculty of Engineering and Architecture, FUMEC University, Belo Horizonte, Brazil \\ ${ }^{3}$ Department of Materials Engineering (SMM), Engineering School of São Carlos (EESC), São Paulo University (USP), São Carlos, Brazil \\ ${ }^{4}$ Centre for Innovation and Technology in Composites (CITeC), Department of Civil Engineering (DECiv), Federal University of São \\ Carlos (UFSCar), São Carlos, Brazil \\ ${ }^{5}$ Department of Structures Engineering (SET), Engineering School of São Carlos (EESC), São Paulo University (USP), São Carlos, Brazil
}

\begin{abstract}
Brazil is one of the countries with the largest reserves of tropical forests. Their rational use ensures sustainability in actions developed by extractive companies. However, for this, to know wood properties of species harvested from these reserves is very important. This research aims to the determination of strength in compression parallel to grain; shear strength and density for (Pouteria sp.), vulgarly called Pariri, a wood from a Northern Brazilian legal reserve. Tests were carried out in accordance with Brazilian standard ABNT NBR 7190: 1997. Results obtained in this study permit to concluded that Pariri Wood presents compatible physical and mechanical properties for use in structural purposes.
\end{abstract}

Keywords Compression parallel strength, Shear parallel strength, Density, Wood

\section{Introduction}

The use of wood in construction is a practice carried out for many years, since humanity needed to protection, to store food, to overcome natural obstacles, among other objectives. For many centuries, also in Brazil, wood has been applied without any quality control in building structures, being employed, often wrong way, favoring the rotting of timber structural elements and/or the ruin of these structures.

Brazil is a country with a large proportion of using wood from native trees to solve building problems, including structures for several purposes. The first buildings held in the country were made with high performance wood, extracted from major forest regions, such as the Amazon Tropical Forest and the Atlantic Forest [1-3].

For the sustainable use of native tropical species, it is fundamentally important establish certificate forest areas, and control the quality of different wood industrialization processes. Certification of production process in which native woods are employed provides assurance of sustainability in this sector [4].

The adequate knowledge of wood properties, whether

* Corresponding author:

diegoestruturas@gmail.com (Diego Henrique de Almeida)

Published online at http://journal.sapub.org/ijme

Copyright (C) 2015 Scientific \& Academic Publishing. All Rights Reserved physical or mechanical, is essential to better direct their use, for example, to timber structures construction [5-8].

Brazilian Standard ABNT NBR 7190:1997 "Design of Timber Structures" [9], in its Annex B, provides guidelines in terms of test methods to determine physical and mechanical properties of native and exotic species. Furthermore, in this Code, Annex E presents values of strength, stiffness and density for several of these wood species.

Density is a basic physical property because its values permit to determine the own weight of the structure and enables to proper estimation of several wood mechanical properties. In general, a wood with higher density will present values of mechanical properties higher when compared with wood species with lower density [10].

Brazilian standard adopts strength in compression parallel to grain as reference mechanical property, in timber structures design. Based on it, other values of strength when wood bars are subjected to different solicitations and angles related to the grain can be estimated [11-15].

Shear strength parallel to grain is also an important parameter for defining use of wood for structural purposes [16].

In this context, the research aims to the experimental determination of density, strength in compression parallel to grain and shear strength parallel to grain of a Brazilian native wood specie called Pariri (Pouteria $s p$.), only recently used 
in construction of timber structures.

\section{Material and Methods}

Tests were carried out in Wood and Timber Structures Laboratory (LaMEM), Structural Engineering Department (SET), São Carlos Engineering School (EESC), São Paulo University (USP).

For this research, specimens were extracted from timber beams which would be applied in roof structures. Those beams were of Pariri Wood specie (Pouteria sp.), come from a Tropical Certified Forest Area, Northern Brazil, and seasoned in standard condition of moisture content (12\%).

For each of the properties determined, twelve specimens were produced, according to ABNT NBR 7190:1997 [6].

Tests to determine strength in compression parallel to grain (Figure 1) and shear strength parallel to grain (Figure 2) were performed in a universal testing machine AMSLER, with load capacity of 25 tons. For density determination, measurements were made of the dimensions of the specimen for determining your volume, after, the respective mass were determined (Figure 3).

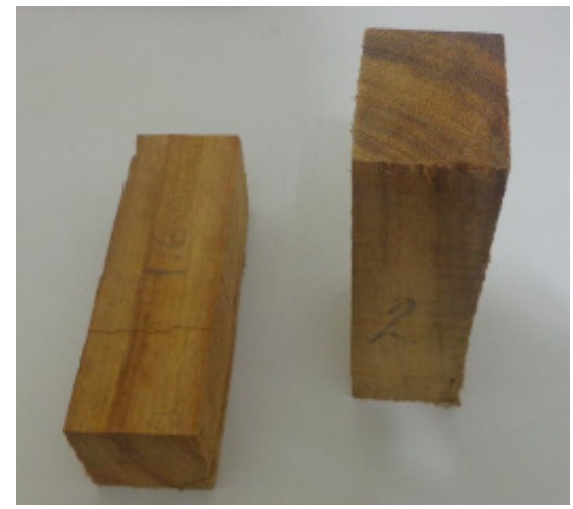

Figure 1. Pariri Wood: specimen for compression parallel test

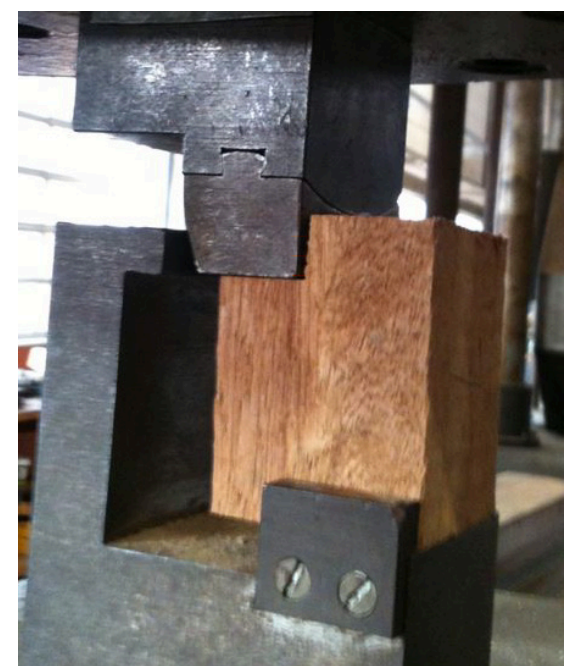

Figure 2. Pariri wood: specimen for shear parallel test

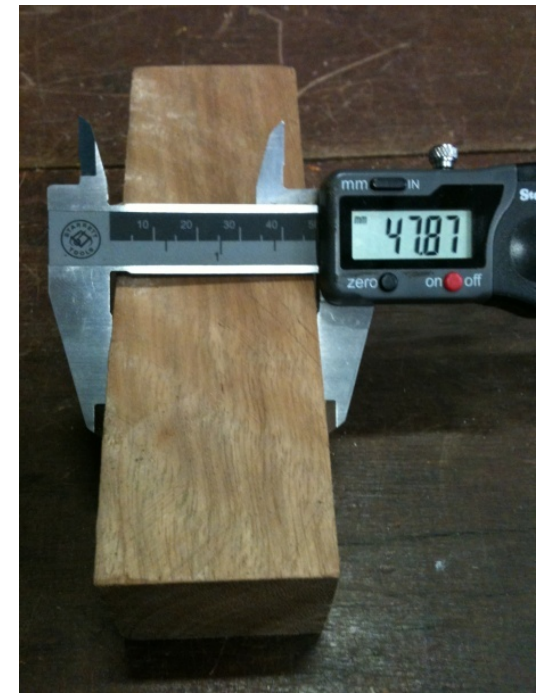

Figure 3. Measurements in Pariri wood specimen for determine the density

Strength in compression parallel to grain strength $\left(f_{c 0}\right)$ is provided by the ratio between the force required to rupture the specimen $\left(F_{c 0}\right)$ and square cross-sectional area of the specimen $\left(A_{c}\right)$ with nominal side $5 \mathrm{~cm}$, according to Equation 1.

$$
f_{c 0}=\frac{F_{c 0}}{A_{c}}
$$

Strength in shear parallel to grain $\left(f_{v 0}\right)$ is provided by the ratio between: force required to rupture the specimen $\left(F_{v 0}\right)$ and nominal area resistant to this request $\left(A_{v}\right)$ (Equation 2).

$$
f_{v 0}=\frac{F_{v 0}}{A_{v}}
$$

Density $(\rho)$ is the ratio between mass $(m)$ of specimen and its volume $(V)$. Specimens to density determination presented moisture content close to $12 \%$, according to Brazilian Code ABNT NBR 7190:1997 [9] (Equation 3)

$$
\rho=\frac{m}{V}
$$

\section{Results}

Table 1 presents mean values $\left(X_{m}\right)$ for strength in compression parallel to grain, strength in shear parallel to grain and density. Moreover, presents also standard deviation $\left(S_{d}\right)$, the variation coefficients $(V C)$ and the number of specimens $(n)$ for each property investigated in this study, for Pariri wood specie.

It can be observed that all values of $\mathrm{VC}$ are inferior to $18 \%$, as is required by Brazilian Code [9], validating the adopted sampling. 
Table 1. Mean values for strength in compression parallel to grain, shear strength parallel to grain and density of Pariri wood specie

\begin{tabular}{cccc}
\hline Properties & $\boldsymbol{f}_{\boldsymbol{c} \boldsymbol{0}}[\boldsymbol{M P a}]$ & $\boldsymbol{f}_{\boldsymbol{v} \boldsymbol{0}}[\mathbf{M P a}]$ & $\boldsymbol{\rho}\left[\mathbf{k g} / \boldsymbol{m}^{3}\right]$ \\
\hline $\boldsymbol{n}$ & 6 & 6 & 6 \\
$\boldsymbol{X}_{\boldsymbol{m}}$ & 70 & 15 & 920 \\
$\boldsymbol{S}_{\boldsymbol{d}}$ & 5 & 2 & 35 \\
$\boldsymbol{V C}[\boldsymbol{[} \boldsymbol{0}$ & 7 & 13 & 4 \\
\hline
\end{tabular}

Physical and mechanical properties presented by Pariri (Pouteria sp.) confirm that its wood can be included in Class C60 (dicotyledonous), according to ABNT NBR 1790:1997, and so be employed in timber construction in this condition.

Mean values of compressive parallel strength of the Pariri wood were close to values found for some other Brazilian native species [11,22].

\section{Conclusions}

Based on results obtained in this research, it's possible to conclude that Pariri (Pouteria $s p$.) is hardly indicated to structural purposes.

\section{ACKNOWLEDGMENTS}

Authors thank to Wood and Timber Structures Laboratory (LaMEM), Structural Engineering Department (SET), São Carlos Engineering School (EESC), São Paulo University, by the materials and resources used in this research. Also, thank CAPES for financial supports.

\section{REFERENCES}

[1] Zenid, G. J. Wood: sustainable use in construction, IPT, 2009.

[2] Almeida, D. H.; Scaliante, R. M.; Christoforo, A. L.; Varanda, L. D.; Lahr, F. A. R.; Dias, A. A.; Calil Junior, C. Tenacidade da madeira como função da densidade aparente, Revista Árvore, 38 (2014) 203-207.

[3] Almeida, T. H.; Almeida, D. H.; Marcolin, L. A.; Gonçalves, D.; Christoforo, A. L.; Lahr, F. A. R. Correlation between dry density and volumetric shrinkage coefficient of three Brazilian tropical Wood species, International Journal of Materials Engineering, 5 (2015) 1-4.

[4] Almeida, D. H.; Ribeiro, A. R.; Oliveira, D. M.; Lima, B. A.; Morais, S. P.; Cunha, F. E. G. FSC Standard application in Brazilian company, Proceedings of VIII Symposium of Applied Sciences of Social and Agricultural Sciences Faculty, Itapeva, Brazil, 2011.

[5] Carrera, M.; Molina, J. C.; Calil Jr., Carlito; Dias, A. A. Previsão do módulo de ruptura à flexão em toras de Eucalyptus sp pelo ensaio de vibração transversal. Mecânica Experimental, v. 20, p. 67-72-72, 2012.

[6] Silva, M. R.; Machado, G. O.; Brito, J. O.; Calil Jr, C.
Strength and stiffness of thermally rectified eucalyptus wood under compression. Materials Research (São Carlos. Impresso), v. 1, p. 1, 2013.

[7] Bertolini, M. S.; Macedo, L. B.; Almeida, D. H.; Icimoto, F. H.; Lahr, F. A. R. Restoration of structural timber elements using epoxy resin: analysis of mechanical properties, Advanced Materials Research, 778 (2013) 582-587.

[8] Almeida, D. H.; Cavalheiro, R. S.; Ferro, F.S.; Almeida, T. H; Christoforo, A. L.; Calil Junior, C.; Lahr, F. A. R. Modulus of elasticity of Schizolobium amazonicum Wood evaluated by transversal vibration technique, Advanced Materials Research, 912 (2014) 247-250.

[9] ABNT NBR 7190:1997. Design of structure of timber. Rio de Janeiro, 1997.

[10] Dias, F. M.; Lahr, F. A. R. Strength and stiffness properties of wood esteemed trough the specific gravity, Scientia Forestalis, 65 (2004) 102-113.

[11] Ferro, F. S.; Icimoto, F. H.; Almeida, D. H.; Christoforo, A. L.; Lahr, F. A. R. Verification of test conditions to determine the compression modulus of elasticity of wood, International Journal of Agriculture and Forestry, 3 (2013) 66-70.

[12] Calil Jr, Carlito; Molina, J. C. Emerging Timber Bridge Program to São Paulo State: A Five-Year Report. Journal of Civil Engineering and Architecture, v. 5, p. 459-464, 2011.

[13] Almeida, D. H.; Molina, J. C.; Almeida, T. H.; Calil Junior, C. Analysis of strength and stiffness of wood from reforestation in compression loads, Proceedings of XIII Brazilian Meeting of Timber and Wood Structures, Vitória, Brazil, 2012.

[14] Scaliante, R. M.; Almeida, D. H.; Macedo, L. B.; Macêdo, A. N.; Calil Junior, C. Creep and compression parallel to grain tests for woods in equilibrium moisture and saturated situations, Wood: Architecture and Engineering, 12 (2011) 19-30.

[15] Almeida, D. H. Proposed test method for determining of the embedment strength of wood, São Carlos, 2014, 130 p. (Master's Dissertation, São Paulo University, USP).

[16] Calil Jr, C.; Lahr, F. A. R.; Dias, A. A. Timber elements design, Manole, 2003.

[17] Almeida, D. H.; Scaliante, R. M.; Macedo, L. B.; Macêdo, A. N.; Dias, A. A.; Christoforo, A. L.; Calil Junior, C. Structural characterization of the Amazonian wood specie Paricá (Schizolobium amazonicum Herb) in members, Revista Árvore, 37 (2013) 1175-1181.

[18] Christoforo, A. L.; Panzera, T. H.; Silva, D. A. L.; Fiorelli, J.; Lahr, F. A. R. Shear and longitudinal modulus of elasticity in structural lumber beams, International Journal of Materials Engineering, 4 (2014) 31-36.

[19] Branco, L. A. M. N.; Lahr, F. A. R.; Chahud, E.; Christoforo, A. L.; Battistele, R. A. G.; Valarelli, I. D. D. Influence of moisture content in some mechanical properties of two Brazilian Tropical Wood species, Advanced Materials Research, 1025-1026 (2014) 42-45.

[20] Chahud, E.; Lahr, F. A. R.; Branco, L. A. M. N.; Christoforo, A. L.; Battistele, R. A. G.; Valarelli, I. D. D. Evaluation of longitudinal modulus of elasticity in wood species for structural application, Advanced Materials Research, 1025-1026 (2014) 192-195. 

the Grain Strengths of Pariri (Pouteria sp.), Brazilian Native Wood Specie

[21] Almeida, D. H.; Chahud, E.; Ferro, F. S.; Poleto, S. F. S.; Almeida, T. H.; Christoforo, A. L.; Lahr, F. A. R. Physical and mechanical properties of Dipteryx odorata (Aublet) Willd, Advanced Materials Research, 1025-1026 (2014) 46-49.
[22] Christoforo, A. L.; Blecha, K. A.; Carvalho, A. L. C.; Rezende, L. F. S.; Lahr, F. A. R. Characterization of tropical wood species for use in civil constructions, Journal of Civil Engineering Research, 3 (2013) 98-103. 